\title{
MEDIA COMPETENCE OF A FUTURE PSYCHOLOGIST AS A CONDITION OF SUCCESSFUL PROFESSIONAL FULFILMENT
}

\author{
Zelenin V. V., Ponomarenko T. I.
}

\section{INTRODUCTION}

Our country and the whole world are undergoing significant changes in all spheres of the society. These changes are driven by information and technological progress. It has a significant impact on both the personal and professional spheres of human life. Large companies, government agencies, businesses and private business owners use innovative technologies in their professional activities. They actively involve the available media in their work: they create websites, online shops, forums, an electronic database, an electronic reporting form, advertise their services on the Internet and create profiles for companies on social networks.

In this way, you can attract new customers, scale your business, find sponsors and partners, create comfortable working conditions for staff, minimize salaries and advertising costs. Such innovations are convenient for companies or institutions and for clients.

The evolution of technology has not gone beyond the psychological services market. Increasingly, psychologists are shifting their professional activities to online format. Currently, it is popular in the work of psychologists to conduct webinars, trainings, workshops, online conferences, online courses, psychological quests and marathons, live broadcasts. At the same time, the quality of service delivery remains high, provided that the communication with the client and the organization of feedback are properly built. But even "live projects" do not lose their relevance. Psychologists also systematically integrate the functionality of social networks into their professional media activities. In this regard, there is a need to use new methods, forms, approaches and technologies in the training of studentspsychologists, taking into account the modern specificity of professional activities of psychological profile specialists.

\section{Fundamentals of media competence of a psychologist}

The modern information world calls for the involvement of media and, consequently, high display of personality. In this regard, the media competence of a specialist has become one of the basic conditions for 
successful professional activity of specialists in different industries and determines the high efficiency of a person in an extremely changing world.

Analysis of a scientific research shows that interest in the media began to emerge in the early twentieth century, both in foreign and domestic studies. M. McLuhan was one of the first to use the term "media", to refer to various means of communication. Later, M. Andersen, C. Worsnop, V. Duncan, D. Katz, A. Kepser, S. Crawford, K. Maywald, D. Mor, J. Pungente, F. Frederking and others joined the discussion. The problem of a psychologist's activity in the media space was revealed in the works of foreign (A. Becker, R. Giles, D. Giles, V. Duke, V. Liaudis, R. McCall, S. Punching, H. Simon, S. Stolz, S. Turkle, etc.) and domestic (O. Adamenko, O. Arestova, V. Bondarovska, A. Hordieieva, V. Zelenin, I. Kotyk, O. Krutko, Y. Maksymenko, L. Naidionova, L. Panchenko, N. Khmil, O. Shmieliova, etc.) scientists.

In the early twentieth century a large part of information and educational functions is gradually moving to the media. Peter Sloterdijk, in the work "Critique of Cynical Reason", writes, "for the first time, they entered a stage of outreach that no rationalist encyclopedia knew, no artistic work, no philosophy of life. Possessing an immense amount, they quickly moved on to what great philosophy could always dream of - to total synthesis, of course, at zero intelligence, in the form of total arithmetic summation. They actually allow us to develop a universal chaotic empiricism, they can tell everything, touch everything, save everything, compare everything. At the same time they represent even more than philosophy - they simultaneously follow the traditions of the encyclopedia and the circus" ${ }^{\text {. }}$.

With the advent of the Internet (the first ARPANET server was installed on September 1, 1969 at the University of California, Los Angeles), the media space has changed significantly and has grown. Skype was created in 2003, and the first social network Facebook - in 2004. Thus, they began to distinguish eight types of environments on the Internet: 1). Co-creation projects (Wikipedia); 2). Blogs and microblogs (LJ, Twiter); 3). Content communities (YouTube); 4). Social networks (VKontakte, Odnoklasniki, Facebook, Instagram); 5). Social networks for finding and establishing business contacts (LinkedIn, Viadeo, Professionals.ru, XING, E-xecutive.ru, MYCO); 6). Messengers (Telegram, WhatsApp, Viber); 7). Virtual game worlds (World of Tanks); 8). Virtual social worlds (Second Life).

Therefore, most of the online environments listed above can be used for professional purposes. We would like to point out that there are social networks of two types: 1) for communication (VKontakte, Odnoklasniki, Facebook, Instagram); 2) for search and establishment of business contacts

${ }^{1}$ Слоттердайк П. Критика цинического разума. Москва : АСТ, 2009. С. 457. 
(LinkedIn, Viadeo, Professionals.ru, XING, E-xecutive.ru, MYCO). The latter, over time, turn into $\mathrm{CV}$ bases for HR professionals.

With the advent of new media means and their gradual integration into all spheres of society, in particular, in the professional, there is a need to develop media competence of specialists of different profiles ${ }^{2}$.

W. Schludermann points out that media competence contains a number of abilities and skills that relate to the media and are about measuring knowledge, perception and active use of media means ${ }^{3}$.

O. Fedorov interprets media competence of a personality as a set of his/her motives, knowledge, abilities, skills that contribute to the selection, use, critical analysis, evaluation, creation and transmission of media texts in different types, forms and genres, analysis of complex processes of functioning media in society. It identifies the following indicators of media competence of the individual:

- Motivational indicator shows us $\mathrm{r}$ what purpose a person or a specialist carries out media activity for, which motives are guided: genre, thematic, emotional, epistemological, hedonistic, psychological, moral, intellectual, aesthetic, therapeutic and others;

- Contact indicator reflects the frequency of contact (communication) with the media, the use of media and the degree of involvement of the individual in the media space;

- Information indicator is responsible for knowledge of the terminology, theory and history of media culture, understanding of the process of mass communication and media influences in the context of the real world, awareness of existing modern media and understanding of their specifics;

- Perceptual indicator demonstrates media literacy ability;

- Interpretative indicator shows the ability of the individual to interpret, analyze media products based on a certain level of media perception and make generalized conclusions;

- Estimated indicator shows the ability to design, create, improve, and distribute one's own media products;

- Practical or operational indicator shows the technical knowledge and skills required to develop, create and distribute media products (such as editing videos or posting on social networks or processing visual content);

- Creative indicator shows the presence of a creative component in various aspects of the activity (perceptual, play, artistic, research and other)

\footnotetext{
${ }^{2}$ Wallace P. The psychology of the Internet. Maryland : Cambridge University Press, 2005. 367 p.

${ }^{3}$ Schludermann W. Media Maturity - The Pedagogic Return to Basics of Media Pedagogy. Vienna : Proceedings1, 999. 345 p.
} 
related to the media, that is, the ability to approach the creation and distribution of their own media texts creatively ${ }^{4}$.

Thus, we see that the media competence of a modern man is a multicomponent phenomenon which contains a number of indicators that determine it. Media competence of the modern psychologist-practitioner implies the presence of a whole spectrum of knowledge and skills that are necessary for successful professional activity in the media space. They include technical, marketing and psychological knowledge and skills. To the technical knowledge and skills we include: the expert's knowledge of all existing media resources; ability to create profiles on social networks; create professional referral groups and business pages; work with accounts, groups and business pages - promote them; create dialogs in chats and messengers, work with them; ability to write posts, post videos, post stories; capture and edit video - create visual content; photoshop skills and services that help you create posters; create personal channels on YouTube and Telegram, hold live broadcasts, broadcasts and conferences; consult with Skype; work with the webinar room; create Google Forms and Landing page - one-page sites; organize the work of chatbots, as well as a range of knowledge related to where, how and when psychologists can appropriately use a particular medium according to its functionality.

The second area of knowledge covers marketing. It is marketing knowledge that empower a psychologist to: identify his or her target audience in order to fulfill professional activity more effectively and accurately; knowledge of what media resources a psychologist can find for his/her ideal client; create and promote text and video content, properly visualize educational content; form trust of the client to the expert, make a person the loyal client; ability to design the profiles in media resources qualitatively, informatively and competitively; create a product line and sales funnel to attract more customers, as well as knowledge of the algorithms of specific social networks.

The range of psychological knowledge and skills include: general personality display; high level of development of communicative media competence; self-control in communication; communicative creativity; work with personal and situational anxiety and fears that interfere with professional activities on the Internet (fear of camera, negative comments and condemnation); high level of development of non-verbal abilities; high emotional intelligence; well-developed creativity and flexibility of behavior; ability to organize feedback during group interaction in online space. All this

\footnotetext{
${ }^{4}$ Федоров А. В. Медиаобразование: история, теория и методика. Ростов : ЦВВР, 2001. 708 c.
} 
knowledge and skills will help the psychologist to carry out his/her professional activity in the Internet space successfully and competitively.

The personal qualities of a psychologist are also very necessary for the formation of media competence and successful implementation of media activities $^{5}$. Namely:

- Personality media skills show a person's acting potential and his/her ability to work on camera (O. Holubieva, L. Naidionova, O. Fedorov);

- Interpersonal skills help not only to perform professional activity in a good manner, but also establish relationships with fellow psychologists and managers of different projects, create new contacts, join interesting events, create collaborative projects, involve the best specialists in their courses, marathons, conferences, agree on advertisements of their products and services, monitor their activities (I. Alekseichuk, N. Ananieva, O. Baryshpolets, V. Labunska, O. Sharykov);

- Emotional intelligence assists a person in establishing new contacts, allows to form the necessary impression of a person and his/her services, helps in resolving and preventing conflict situations, helps to create trust in new clients and loyalty in regular ones (V. Boiko, A. Lukasevych, O. Romanova, O. Rodina, P. Prudkov, O. Sapohova, N. Poviakel, N. Chepelieva);

- Reflection allows you to analyze and evaluate own thoughts, actions and reactions and draw appropriate conclusions (A. Lukasevych, L. Naidionova);

- Flexibility of behavior helps to find a way out quickly in difficult or emergency situations, allows to adapt to the client or employer, allows to be mobile and effective in professional activity at most, widens the range of opportunities, promotes self-actualization and professional maturity of a specialist, helps to reach a new level of potential realization (L. Mitina, A. Sheiko);

- Creativity allows you to create, organize and promote unique psychological products and services interestingly. It helps to find a way out in difficult situations, develops the creative potential of the individual, promotes the development of his/her productivity, helps to act in crisis or emergency situations and promotes the professional maturity of the psychologist and significantly expands his/her range of opportunities (O. Voznesenska, V. Sierikov).

Information and technological progress has determined the emergence of a specific element of media competence of the individual, in general, and

${ }^{5}$ Zelenin V., Ponomarenko T. Media competence as a factor of professional selfrealization of a practical psychologist. New stages of development of modern science in Ukraine and EU countries. Riga, Latvia : Baltija Publishing, 2019. P. 357-373. 
psychologists, in particular. It became a communicative media competence. As early as the 1990s, it was believed that communicative media competence was a competence in the perception, creation and transmission of messages through technical systems, taking into account their specificity, features and limitations, based on critical thinking, as well as the ability to mediate with people ${ }^{6}$.

Consequently, communicative media competence of a psychologist is a component of media competence, which is the presence of the necessary knowledge and skills for the perception, analysis and creation of media texts using modern media, taking into account their specificity, target audience, functional features or limitations. It has three types: text, video and live communication with the client and is implemented in three directions: education, promotion of own services, individual or group counseling, each of which performs a number of tasks.

\section{Positioning of a psychologist in social networks}

Today media means are the primary means of engaging a client with a psychologist, and it is not important for a specialist to work online or "live". Anyone can open a profile of any specialist in social networks and make the impression about this person as a professional before personal acquaintance. Accordingly, there is a need to form a correct positioning of a psychologist in the media space. The psychologist can perform this positioning using a personal brand.

Recently, the problem of personal brand is very relevant in various fields of knowledge (marketing, psychology, economics, law, sociology, political science and so on), and especially its practical part is in demand. Therefore, this issue is constantly being researched by scholars in various fields of knowledge. The works of foreign (A. Azulay, J. Aaker, L. Buk, M. Gobe, J. Kapferer, F. Kotler, D. McNally, H. Rampersad, I. Rhine, E. Romat, T. Peters , M. Stoller, M. Thomson, M. Hamlin) and domestic colleagues (O. Bilovodska, T. Lebedeva, L. Sviridova, O. Rotov, N. Ivashova, V. Isaieva, L. Sviridova, O. Teletova, M. Puzikova) are very interesting to us.

Branding is a powerful method that allows you to form a vision of products or services to customers and influence the consumer behavior ${ }^{7}$.

The term "personal brand" originates from the article "The Brand Called You" by Tom Peters ${ }^{8}$, one of the world's leading business experts, published

\footnotetext{
${ }^{6}$ Шариков А.В. Медиаобразование: мировой и отечественный опыт. Москва : НИИ СО и УК АПН СССР, 1990. 64 с.

${ }^{7}$ Біловодська О., Пузікова М. Аналіз і оцінка персонального брендингу в умовах підвищення професійного успіху особистості. Маркетинг і менеджмент інновацій. 2011. Вип 4. С. 67-74.
} 
in 1997. Peters defines a personal brand as, above all, what other people think of us, is our image in other people's minds; this is how we are seen and perceived; it is our image that generates added value and creates benefits for us. Brand is also understood as a system of parameters that are part of the image of the individual, forming his/her image and, accordingly, recognition and positioning.

A. Azulay and J. Kapferer, understand personal brand as a set of individual personality traits that both form and associate with the brand ${ }^{9}$. Accordingly, the psychologist's personal brand is a set of his/her individual qualities of personality, expertise and professional experience, which form in the minds of clients the idea of a specialist as a professional in the particular subject. Its presence is especially important in the pursuit of professional activity in the media space.

The most common model is the G. Mohanta brand model "Bate's Brand Wheel" $"$, which includes the following structural components:

- Core of the brand is the main offer (psychologist's expertise);

- Individuality is the individual qualities and personal characteristics of the psychologist;

- Values are the skills, knowledge, talents, abilities, professional level of a specialist;

- Advantages are advantages over others - special features (uniqueness of your offer: price, format of the event, convenient location of the office where the psychologist works, etc.);

- Attributes are appearance, image, manner of speaking, facial expressions, gestures, behavior of a specialist, as well as packaging of products and services (banners, advertising, video quality, design of events, etc.).

The core of a psychologist's brand is his/her expertise, uniqueness of experience, author's refinements - his/her products and services (consultations, therapy, coaching sessions, workshops, trainings, books, etc.). The individuality of the personal brand of the psychologist is made up of his/her individual-personal qualities. This is his/her character, type of temperament, specific personality traits and skills. The list of personal characteristics of a specialist, which allow him/her to be congruent with the client's expectations. The unit of values is the beliefs, the life principles of the specialist, the attitudes, social and life position, values, attitude towards

8 Peters T. The Brand Called you Fast Company. 1997. URL: https://www.fastcompany.com/28905/brand-called-you (Last accessed: 18.01.2019).

9 Azoulay A., Kapferer J. Do brand personality scales really measure brand personality? Brand Management. 2003. Vol 11. P. 143-155.

10 Масальский Д. Анализ основных брендинговых моделей. Bonpocbl современной науки и практики. 2010. Вып. 46 (29). С. 242-250. 
oneself, colleagues, clients, family and others. The psychologist's benefits include: the quality and uniqueness of his/her products and services, his/her own experience, the convenience of the services provided, pricing policy, the scope of events, etc. Appearance, image, facial expressions and gestures also play an important role in the formation of the psychologist's personal brand. They help to meet new people, make contacts, establish cooperation, join interesting projects and form a trusting attitude towards oneself as a professional. Also it is important to have the "packing of products" and services: designing a psychologist profile, banners, advertising leaflets, business cards, website, designing "live" events, etc.

Thus, we see that the personal qualities, professional competence, expertise and uniqueness of products and services and appearance take an important place in the formation of the personal brand of the psychologistpractitioner. All these components of the personal brand should be clearly highlighted when creating a specialist profile on social networks and other media resources. In order to create an effective personal brand of a psychologist, it is important to know what his/her strengths, expertise, uniqueness and competitive advantage are. And the strengths need to be developed, demonstrated and emphasized.

Benefits of a personal brand for a psychologist:

- It forms trusting attitude of clients towards the psychologist;

- It gives the opportunity to scale the psychological business and enter the foreign market;

- It increases popularity and opportunities to promote oneself, products and services;

- It gives the ability to attract and retain more customers;

- It helps to increase profit.

Forming the personal brand of the practicing psychologist, we also formulate his/her positioning - providing specific insights into the client's mind about a product or service provided by a psychologist who is clearly associated with a specific specialist and is beyond doubt. It allows the psychologist to formulate a range of questions with which he/she works.

When forming positioning, a psychologist can use the 5W Mark Sherrington Technique ${ }^{11}$, where positioning should answer 5 main questions: Who? - Who is this person, what education and achievements he/she has and why he/she has the right to work with clients; What? - What are the problematic situations you can refer to this psychologist; Where? and When? - Where and when you can find a specialist - contact details; Why? - Why you can refer to this psychologist. In recent years another question has arisen

11 Sherrington M. Added value: the alchemy of brand-led growth. New York : Palgrave Macmillan, 2003. P. 40. DOI 10.1057/9780230513488. 
(How?) because of the increased competition and the active development of media. It highlights the important details of the collaboration and explains how this work will be done.

Thus, a personal brand opens up new opportunities for the psychologist and ensures his/her constant and personal development, and the correct positioning allows to attract the target audience, be competitive and effectively advertise his/her own services. So, there is a need for the formation of knowledge, skills, as well as for the development of personal qualities which are necessary for the successful work in the media space at the stage of studying at the University.

\section{Results of the research}

The third-year students of the Faculty of Psychology at National Pedagogical Dragomanov University and the fourth year students of the Public Employment Service Training Institute $(n=98)$ aged 19 to 46 years participated in our survey. The psychologists-practitioners $(n=64)$ aged from 23 to 64 years, took part in the survey as well. Among psychologists there were school psychologists, kindergarten psychologists, coaches, art therapists, counselors and psychotherapists in the survey.

Our research can be divided into two large blocks. In the first block, using the content-analysis method, we identified functional elements of social networks Facebook and Instagram practicing psychologists can use to position themselves, as well as the types of content they can work with. Using our questionnaire, in the second block we empirically examined the level of involvement of practicing psychologists and students psychologists in the media space, as well as the extent to which they use the opportunities of the Internet in their professional activities.

Currently, social networks are the most convenient way of the professional activities in the media space. In 2017 (after the law on the prohibition of Russian social networks VKontakte and Odnoklasniki), Facebook and Instagram gained a considerable popularity. Their functionality allows you to embody all possible forms of a psychological work online and display a wide range of information about the specialist. The social network Facebook offers its users four sectors where they can position themselves:

1) Photo-space - where experts can usually demonstrate information about themselves as specialists (list of the regalia); a list of topics they work with (expertise); advertising of upcoming events they plan to hold or will participate in (trainings, workshops, webinars, conferences); photo ads of upcoming event (marathon, webinar, live broadcast, festival, conference); 
2) Brief information about oneself - information about oneself as a specialist (education and list of one's regalia); a list of topics a specialist works with (specialization);

3) Information about oneself - where a psychologist indicates his/her city of residence, marital status, place of study, place of work, projects where he/she participates and the business pages he/she manages;

4) Content is a post that relates to psychology in general and to the narrow specialization of a specialist, in particular, as well as a personal life.

Instagram profile differs greatly. It offers its users:

1) Profile photo - where the user places his/her own photo or a company logo. Recent researches show that it is the most beneficial for a business owner to place his/her photo with a tool that is associated with professional activities or in the appropriate location. For example, for a tutor it is a board, a book or a pointer, for a hairdresser it is scissors, for a fitness trainer - a photo in the gym, and for a psychologist it is a book;

2) Profile name - the name must include your name or initials and a word that is associated with your activity. For example, @ lena.druma_koach @ anna_psychology, @ anastasia_trener);

3) Profile heading - a psychologist places his/her full name in the original language and brief information about his/her services, psychological products or expertise and contact information. For example, Maria Ivanova child psychologist: work with children's fears and phobias, tel. +380653456367 );

4) Active link - where you can post links to your site, to a specific video, to other social networks, etc.;

5) Content - your posts or videos that have psychological or personal content.

Taking into account the functionality of the modern media, we distinguish such forms of media communication as: text-posts on social networks, personal blogs, text messages, e-mail, tweets, etc; video-videos on Facebook, Instagram, YouTube or Telegram channel, stories on Instagram; "live - communication", real-time communication via video messaging, webinars, online conferencing, Skype.

Content is one of the main ways to form the necessary, positive and trusting attitude towards oneself as a specialist. After analyzing the content published by psychologists on social networks, we formed the following classification of the content on social networks: 1) type of information submission: visual (video, pictures, photos, pages, live program), text (posts); 2) content load: informational (problem solving, event notification, etc.), motivational (call to action, conference response, call to attend the event), personal (life stories, stories about ones' own insights). 
Users of social networks (according to the number of "likes", comments and shares) are more affectionate with posts of personal and informationalmotivational nature. And they also favor entertainment videos and posts.

Using content analysis method, we have identified eleven types of posts that can be used by a psychologist on social networks to create high quality content:

- Post-greeting or post-acquaintance is a post where a psychologist talks about oneself, about one's professional activity, about services and goods and gets acquainted with the audience;

- Post-event is a post where a psychologist announces to the audience about a training or workshop that he/she is organizing in the near future;

- Post-sale is a post where a psychologist advertises and offers to buy products or services;

- Post-congratulation is a post where a psychologist congratulates clients on holidays and tells about interesting days that are dedicated to certain events: "Hugs Day", "Laugh Day", etc;

- Post-survey is a post where a psychologist can ask audience about their attitude to a particular problem, event or phenomenon, or ask what questions clients would like to receive from him/her or what topics they would like to talk about or read;

- Post-recommendation is a post where a psychologist reports on upcoming activities in the city, country, world or online environment or recommends colleagues;

- Post-schedule is a post where a psychologist reports on all his/her projects, for example, for a month;

- Post-draw is a post where a psychologist can draw tickets to the events, his/her psychological products (books, etc.), in order to attract new audience and build client confidence;

- Post-information is a post where a psychologist reports useful information that has psychological content and relates to his/her specialization;

- Life-style post is a post where a psychologist talks about his/her personal life;

- Post-profession is a post where a psychologist talks about the professional development courses he/she attends.

Therefore, a practitioner - psychologist can shape his/her positioning using social networking and high quality text or video content.

In order to empirically investigate the technical component of media competence of all participants in the research, as well as their level of involvement in media space, we created a questionnaire. It consists of 
14 questions and allows to assess the psychologists' involvement in professional media activities and their level of technical knowledge and skills.

As a first step, we examined the level of practitioners - psychologists' involvement in media space and their media competence. Social networks are the most convenient, large-scale and accessible to use now. The findings show that $100 \%$ of those polled have profiles on Facebook, $86 \%$ - on Istagram and $58 \%$ - on Telegram. $86 \%$ of psychologists use social networks in their professional activities, low level of usage $-32 \%$, medium level of usage $-44 \%$ and high level of usage $-24 \%$. We also found that $69 \%$ of those surveyed use Skype in their professional activities. Social networks also allow to create and maintain professional referral groups and business pages. $61 \%$ of respondents use this form of professional activity in the Internet environment. 50\% of those polled have their own YouTube channel and only $24 \%$ of them have their own sites. Having analyzed the data, we can conclude that the vast majority of practicing psychologists, namely $86 \%$ of them, carry out their professional activities on social networks. We consider such results positive in view of the age of the majority of the participants.

In recent years, webinars, workshops and online trainings have become increasingly popular. We found out that $100 \%$ of participants of our experiment attend these events and $66 \%$ of them have the experience for conducting such events. $52 \%$ of the participants have held online conferences, $69 \%$ of them have attended conferences and only $17 \%$ of respondents have no experience in this format. $42 \%$ of those polled have experience in marathons, $65 \%$ of people in the survey have participated and $17 \%$ of respondents have no such experience.

Online space enables practicing psychologists not only to work, but to learn in this format. $83 \%$ of those surveyed have online learning experience. They attended webinars, workshops, lectures of foreign and domestic coaches, workshops. They participated in online conferences in their specialization and passed entire training courses in the Internet space. $84 \%$ of the respondents were satisfied with this format and were able to successfully put their professional knowledge and skills into their practice with clients.

We also explored the technical skills that psychologists need to produce high quality content. The results show that $41 \%$ of people in the survey are able to shoot and edit videos, 55\% of them are able to create advertising banners and process photos or pictures. $66 \%$ of respondents know how to create Google Forms, $10 \%$ of those surveyed know how to create one-page sites, and $96 \%$ of participants of the experiment know how to make presentations.

In the last item of our questionnaire, we asked to list the opportunities that psychologists have in professional activities in the media space. Thus, according to the interviewed psychologists, using media space allows: develop in the profession and not stop there; learn from the best experts from different countries 
in a convenient format; constantly travel and not lose customers; learn about interesting psychological events that happen in the city, country and world; practice co-working - find new business partners; expand the audience and scale the psychological business; promote one's own psychological products and services; use new formats of work (webinars, marathons, quests); opportunity to share knowledge, help more people.

Thus, we see that the vast majority $-86 \%$ of psychologists in the survey practice not only online training, but also professional activities in the online space. They are gradually mastering the functional potential of the Internet environment and clearly understand what opportunities the media space opens for them.

The next step is to investigate the level of involvement of students psychologists in the online space and their media competence. Initially, we found that $83 \%$ of students in the survey already have professional experience: in school $-44 \%$, in kindergarten $-19 \%$, in universities and colleges $-7 \%$, volunteerism $-7 \%$, educational and industrial practice $55 \%$, in summer camp $-4 \%$. And only $17 \%$ of respondents have no experience as a psychologist.

The vast majority of students surveyed ( $82 \%)$ have experience with children, $18 \%$ of them have worked with children with special needs, $11 \%$ of respondents have experience with adults and only $4 \%$ of interviewed students have worked with families and adolescents. 35\% of future psychologists in the survey have experience of professional cooperation with school psychologists, 30\% - with psychotherapists, 25\% - with speech therapists, $10 \%$ - with preschool teachers, $10 \%$ - with teachers and 5\% with medical professionals.

We have found out that $61 \%$ of students attend additional events (workshops, conferences, trainings, festivals) to enhance their professional skills. Thus, such indicators show that $83 \%$ of future psychologists already have experience in professional work in various fields of providing psychological services at the stage of University study. They take additional measures to improve their knowledge, practical skills and professional experience. We consider such a result positive, as the training in this way allows specialists to adapt faster at the place of work after graduation, already have professional experience, own experience and projects, be more competitive in the market of psychological services and choose their narrow specialization and become an expert.

Concerning the media competence of students-psychologists and their level of involvement in the media space, the situation is much worse. The findings show that $61 \%$ of those polled have Facebook profiles, $82 \%$ of them - Istagram profiles and $89 \%$ respondents - Telegram profiles. Only $22 \%$ of respondents use social networks in their professional activities. Of 
these interviewed, $65 \%$ of people have low level of social networks usage in their professional activities and $35 \%$ of them use social networks in their professional activities at the average level. We also find that only $7 \%$ of those polled use Skype's professional capabilities. And only $7 \%$ of students surveyed have their own YouTube channel. 7\% of respondents have professional groups and business pages on social networks. And 39\% of them practise online training. These results indicate that students psychologists are involved in the online space, but they use it primarily for personal purposes rather than professional activities.

Nowadays it is important to attend various events online (webinars, trainings, master classes). $36 \%$ students attend such events and only $4 \%$ of them have experience of organizing such events. $18 \%$ of students have participated in psychological marathons, only $4 \%$ of respondents have conducted them and $79 \%$ of them do not have such experience.

In terms of technical knowledge and skills, 39\% of future psychologists are able to shoot video and edit it. $50 \%$ of them know how to create banner ads and process photos or pictures. 25\% of those polled know how to create Google Forms, $21 \%$ of respondents know how to create one-page sites and $82 \%$ of them know how to make presentations.

According to future psychologists, the Internet space offers them the following opportunities: a new circle of acquaintances; high speed of access to information and a wide variety of its search; bigger customer base; promotion of basic psychological knowledge; improving of one's own knowledge; opportunity to express oneself; communication with people from different countries; ability to always be in touch; distance learning; information about people's interests in different areas. Thus, we see that most of the opinions of the students - psychologists describe only the general features of the Internet environment, and they still have little understanding of Internet possibilities for professional activities.

Therefore, it can be concluded that students - psychologists are involved in the media space, but they use it in their professional activities a little unlike psychologists-practitioners. About 50\% of students in the survey have the technical knowledge and skills that are required to work in online format, but they almost do not understand the capabilities of the online environment for their professional activities. 
Table 1

Comparative characteristics of the media use in the professional activities of psychologists-practitioners and students-psychologists (in \%)

\begin{tabular}{|c|c|c|}
\hline Media means & $\begin{array}{c}\text { Psychologists- } \\
\text { practitioners }\end{array}$ & Students-psychologists \\
\hline Social networks & $86 \%$ & $22 \%$ \\
\hline Skype & $69 \%$ & $7 \%$ \\
\hline $\begin{array}{c}\text { Groups and business- } \\
\text { pages }\end{array}$ & $61 \%$ & $7 \%$ \\
\hline YouTube-channel & $50 \%$ & $7 \%$ \\
\hline Website & $24 \%$ & $4 \%$ \\
\hline $\begin{array}{c}\text { Webinars and } \\
\text { workshops }\end{array}$ & $66 \%$ & $0 \%$ \\
\hline Online-conferences & $52 \%$ & $4 \%$ \\
\hline Marathons & $42 \%$ & $39 \%$ \\
\hline $\begin{array}{c}\text { Professional online } \\
\text { studies }\end{array}$ & $83 \%$ & $50 \%$ \\
\hline Technical skills & $70 \%$ & \\
\hline
\end{tabular}

Thus, by comparing two survey samples, we can conclude that there is a need to introduce appropriate subjects and special courses in the educational process of future psychologists in order to deepen their knowledge, develop the necessary skills and experience to work in the online space, increase their competitiveness in the market of services and opportunities implementation of own ideas and projects.

\section{CONCLUSIONS}

Media space is gradually filling all facets of the society. It shows particularly positive results in the professional field. The advent of the Internet and the constant development of modern media have determined the emergence of a specific type of personality competence-media competence. By this phenomenon we mean the set of knowledge of the skills that a person needs to perceive, analyze, create and promote media texts.

For the last ten years, the market for psychological services has been gradually transformed into online format. The main tool of the psychologist's activity is communication with clients. Therefore, activities in this way require the development of communicative media competence of the specialist. Communicative media competence is a component of media competence that consists of having the necessary knowledge and skills to perceive, analyze and create media texts with the help of modern media, taking into account their specificity, target audience, functional features or limitations. It has three types: text, video and live communication with the client and is implemented in three directions: education, promotion of own 
services, individual or group counseling, each of which performs a number of tasks. One of the conditions for the effective activity of the psychologist in the online format is correctly formed positioning, which is realized with the help of the personal brand of the specialist and allows him/her to form the necessary impressions about his/her activity in the client's mind.

The empirical research found that the social networking sites Facebook and Instagram provide about five functional elements where psychologists can position themselves. We also distinguish three types of media communication: text, video and live communication. Using contentanalysis method, we have developed the classification of content on social networks. Accordingly the content can be divided into: 1) type of information submission: visual (video, pictures, photos, pages, live broadcasts) and textual (posts). 2) content load: informational (disclosure of a problem issue, event notification, etc.); motivational (call to action, conference response, call to attend the event); personal (life stories, stories about own insights). We have also identified eleven types of posts that psychologists can publish to create high quality content.

We have found that the vast majority $-86 \%$ of psychologists practise professional activities in the online space. They are gradually mastering the functional potential of the Internet environment and clearly understand what opportunities the media space opens for them. Students-psychologists, unlike practicing colleagues, hardly use online space in their professional activities. About $50 \%$ of students have the technical knowledge and skills that are required to work in online format, but they almost do not understand the capabilities of the online environment for their professional activities. Thus, the results of theoretical and empirical research indicate the need for the use of new forms, methods, approaches, the creation of problem groups, special courses and technologies in the preparation of future psychologists in order to deepen their knowledge, the formation of skills that are necessary for work in modern conditions.

We plan further scientific activities in the theoretical and empirical study of psychological factors of the communicative media competence formation in future psychologists and in the creation of social-psychological training course for the development of communicative media competence of students and in the consideration and introduction of new forms and special course on media competence of future specialists.

\section{SUMMARY}

The article describes the theoretical and empirical analysis of the media competence phenomenon of a future psychologist. It has been determined that a psychologist's media competence is a set of knowledge and skills that a specialist needs to fulfil professional activity in the media space 
successfully. We have also found that an important component of a psychologist's media competence is his/her communicative media competence. The empirical study presents two survey samples of 162 individuals in total: practicing psychologists $(n=64)$ and studentspsychologists $(n=98)$. We have identified functional possibilities of social networks for successful positioning using the method of content-analysis. Also we have defined 11 types of posts for psychologists to create high quality psychological content. And also we have examined the level of involvement of psychologists and students in the media space, as well as their level of media competence, using our questionnaire. The results of the study showed that $100 \%$ of psychologists and students are involved in the media space. $86 \%$ of psychologists and only $22 \%$ of students use the opportunities of online space in their professional activities. About $70 \%$ of psychologists and 50\% of students have the necessary technical knowledge and skills to work in the online environment. Thus, there is a need to use new methods, forms, technologies in the process of training of future psychologists in accordance with the realities of the modern world.

\section{REFERENCES}

1. Біловодська О., Пузікова М. Аналіз і оцінка персонального брендингу в умовах підвищення професійного успіху особистості. Маркетинг і менеджмент інноващій. 2011. Вип. 4. С. 67-74.

2. Масальский Д. Анализ основных брендинговых моделей. Вопросы современной науки и практики. 2010. Вып. 46 (29). С. 242-250.

3. Слоттердайк П. Критика цинического разума. Москва : АСТ, 2009. $800 \mathrm{c}$.

4. Федоров А.В. Медиаобразование: история, теория и методика. Ростов : ЦВВР, 2001. 708 с.

5. Шариков А.В. Медиаобразование: мировой и отечественный опыт. Москва : НИИ СО и УК АПН СССР, 1990. 64 с.

6. Azoulay A., Kapferer J. Do brand personality scales really measure brand personality? Brand Management. 2003. Vol 11. P. 143-155.

7. Peters T. The Brand Called you. Fast Company. 1997. URL: https://www.fastcompany.com/28905/brand-called-you (Last accessed: 18.01.2019).

8. Schludermann W. Media Maturity - The Pedagogic Return to Basics of Media Pedagogy. Vienna : Proceedings1, 999. 345 p.

9. Sherrington M. Added value: the alchemy of brand-led growth. New York : Palgrave Macmillan, 2003. 203 p. DOI 10.1057/9780230513488.

10. Wallace P. The psychology of the Internet. Maryland : Cambridge University Press, 2005. 367 p. 
11. Zelenin V., Ponomarenko T. Media competence as a factor of professional self-realization of a practical psychologist. New stages of development of modern science in Ukraine and EU countries. Riga, Latvia : Baltija Publishing, 2019. P. 357-373.

\section{Information about the authors:} Zelenin V. V.,

Ph.D. in Psychological Sciences, Associate Professor at the Political Psychology and Social Legal Technologies Department National Pedagogical Dragomanov University 9, Pyrogova st., Kyiv, Ukraine

Ponomarenko T. I., Postgraduate Student of Political Psychology and Social Legal Technologies Department National Pedagogical Dragomanov University 9, Pyrogova st., Kyiv, Ukraine 